\title{
Efficacy of a contact lens cleaning device and its enhancement of the performance of contact lens care products
}

\author{
C P Ifejika, L McLaughlin-Borlace, V J Lucas, A D G Roberts, J T Walker
}

\begin{abstract}
Background-Corneal infections due to contact lens contamination are risks associated with contact lens wear. Care systems which reduce these risks are desirable.

Methods-This study evaluated a contact lens cleaning device using normal saline initially and then four contact lens solutions.

Results-Using saline, six out of 10 tests resulted in complete removal of challenge organisms or showed reductions to 10 $\mathrm{cfu} / \mathrm{ml}$ or $<10 \mathrm{cfu} / \mathrm{ml}$. Tests upon organism using multipurpose solutions showed $>6$ log reductions in 2-3 minutes. With laboratory made biofilms, similar results were obtained.

Conclusions-This device improves lens cleaning and enhances lens care solutions. When used correctly it should lead to significant reductions in microbial keratitis associated with inadequate contact lens hygiene.

(Br F Ophthalmol 2000;84:539-541)
\end{abstract}

The incidence of microbial keratitis in contact lens wear appears to be increasing and indications are that up to $30 \%$ of corneal ulcers are associated with contact lens wear. ${ }^{1}$ Lens wearers are increasingly seen in accident and emergency departments of certain hospitals. ${ }^{2}$ A contributing factor to lens wear complication is microbial contamination, and reports suggest that up to $95 \%$ of lenses in use are contaminated. ${ }^{3}$ Physical cleaning of lenses and lens cases, helps to reduce micro-organisms before chemical disinfection. ${ }^{4}$

Contact lens wearers and eye care practitioners may rely too much upon contact lens solutions to reduce microbial contamination. Studies indicate that several multipurpose solutions and peroxide systems are not able adequately to disinfect concentrations of bacteria (for example, Staphylococcus aureus) of $10^{7}-10^{8} \mathrm{cfu} / \mathrm{ml}$. The studies show that bacteria can survive chemical disinfection ${ }^{5}$ and they describe resistance to hydrogen peroxide by Candida parapsilosis, a yeast associated with cutaneous infections. ${ }^{6}$

Daily cleaning of contact lenses is not always properly performed by lens wearers. ${ }^{78}$ Levels of microbial contamination of $10^{8} \mathrm{cfu} / \mathrm{ml}$ and above are common in used contact lens cases. ${ }^{17}$ This indicates that many commercially available lens care systems may not be adequate on their own. Use of monthly dispos- able lenses may encourage less diligence in cleaning lenses. ${ }^{9}$ Therefore, an ideal care system needs to eliminate the qualitative test of "rub and rinse" and substitute a more reliable method for cleaning contact lenses.

Devices for cleaning lenses that were marketed in the past, were generally found to be limited when tested with normal saline alone. ${ }^{10}$ Efron et al evaluated a standing wave device and an ultrasound unit, ${ }^{11}$ with standing wave providing little if any reduction to the microorganisms tested and ultrasound producing only minimal reduction over a 22 minute period of operation.

\section{Materials and methods}

The device is commercially available and is manufactured by a LensCare Ltd. At the heart of the system is a multidirectional, vibration generating device which is completely new to this field. It is a small battery operated device which produces incredible turbulence within the lens case, resulting in very thorough cleaning.

The contact lenses used in the tests were sterile, non-ionic low water content lenses (Medalist Polymacon, Bausch and Lomb), and high water content ionic contact lenses (Acuvue daily disposable, Johnson and Johnson). The saline was Oxysept (Allergan) sterile buffered saline. The care products used were 10:10 (Ciba Vision), Optifree (Polyquad, Alcon), Complete (Polyhexamethylene, Allergan), and SOLOCare (Polyhexanide, Ciba Vision).

TEST ORGANISMS AND CULTURE MEDIA

The test organisms were: Pseudomonas aeruginosa, American Type Culture Collection (ATCC)-9027, Staphylococcus aureus (ATCC)27735, Serratia marcescens (ATCC)-14756, Candida albicans, National Collection of Pathogenic Fungi (NCPF)-3324 and Fusarium solani, International Mycological Institute (IMI)-215765. The culture mediums used were: potato dextrose agar (PDA); tryptone soya agar (TSA), and Sabouraud dextrose agar (SDA).

EVAluation OF THE DEVICE

The device was tested according to the repetitive treatment method detailed in EN 1174-2, 1996, "Sterilisation of medical devices, Estimation of the population of micro-organisms on product. Part 2: Guidance". The technique describes the repeated reduction of microorganisms by a given method until there is no significant increase in the number of
Accepted for publication 13 January 2000 
Table 1 Log reduction of challenge organisms using normal saline

\begin{tabular}{|c|c|c|c|c|c|c|}
\hline \multirow{2}{*}{$\begin{array}{l}\text { Testing } \\
\text { procedure }\end{array}$} & \multirow{2}{*}{$\begin{array}{l}\text { Lens } \\
\text { type }\end{array}$} & \multicolumn{5}{|c|}{ Test organisms and the log reductions after testing (cfu/ml) } \\
\hline & & $P$ aeruginosa & $S$ aureus & $S$ marcescens & $C$ albicans & $F$ solani \\
\hline Test & $\begin{array}{l}\text { HWI } \\
(\mathrm{n}=4)\end{array}$ & $\begin{array}{l}5.0(\mathrm{TK})^{\star} \\
(\mathrm{SD}=0) \\
(\mathrm{N}=4)\end{array}$ & $\begin{array}{l}4.0(\mathrm{TK}, \mathrm{L})^{\star} \\
(\mathrm{SD}=0) \\
(\mathrm{N}=4)\end{array}$ & $\begin{array}{l}3.0 \\
(\mathrm{SD}=0.35) \\
(\mathrm{N}=4)\end{array}$ & $\begin{array}{l}5.0(\mathrm{LT})^{\star} \\
(\mathrm{SD}=0.24) \\
(\mathrm{N}=4)\end{array}$ & $\begin{array}{l}4.0(\mathrm{TK}, \mathrm{L})^{\star} \\
(\mathrm{SD}=0) \\
(\mathrm{N}=4)\end{array}$ \\
\hline Control & $\begin{array}{l}\text { HWI } \\
(\mathrm{n}=4)\end{array}$ & $\begin{array}{l}2.0 \\
(\mathrm{SD}=0.25) \\
(\mathrm{N}=4)\end{array}$ & $\begin{array}{l}2.5 \\
(\mathrm{SD}=0.80) \\
(\mathrm{N}=4)\end{array}$ & $\begin{array}{l}2.0 \\
(\mathrm{SD}=0.35) \\
(\mathrm{N}=4)\end{array}$ & $\begin{array}{l}3.0 \\
(\mathrm{SD}=0.20) \\
(\mathrm{N}=4)\end{array}$ & $\begin{array}{l}3.2 \\
(\mathrm{SD}=0.95) \\
(\mathrm{N}=4)\end{array}$ \\
\hline Test & $\begin{array}{l}\mathrm{LWN} \\
(\mathrm{n}=4)\end{array}$ & $\begin{array}{l}4.5 \\
(\mathrm{SD}=0.25) \\
(\mathrm{N}=4)\end{array}$ & $\begin{array}{l}5.0(\mathrm{~T})^{\star} \\
(\mathrm{SD}=0.25) \\
(\mathrm{N}=4)\end{array}$ & $\begin{array}{l}3.5 \\
(\mathrm{SD}=0.23) \\
(\mathrm{N}=4)\end{array}$ & $\begin{array}{l}3.5 \\
(\mathrm{SD}=0.66) \\
(\mathrm{N}=4)\end{array}$ & $\begin{array}{l}3.0(\mathrm{TK}, \mathrm{L})^{\star} \\
(\mathrm{SD}=0.4) \\
(\mathrm{N}=4)\end{array}$ \\
\hline Control & $\begin{array}{l}\mathrm{LWN} \\
(\mathrm{n}=4)\end{array}$ & $\begin{array}{l}2.5 \\
(\mathrm{SD}=0.55) \\
(\mathrm{N}=4)\end{array}$ & $\begin{array}{l}2.0 \\
(\mathrm{SD}=0.35) \\
(\mathrm{N}=4)\end{array}$ & $\begin{array}{l}2.5 \\
(\mathrm{SD}=0.15) \\
(\mathrm{N}=4)\end{array}$ & $\begin{array}{l}2.5 \\
(\mathrm{SD}=0.37) \\
(\mathrm{N}=4)\end{array}$ & $\begin{array}{l}2.0 \\
(\mathrm{SD}=0.72) \\
(\mathrm{N}=4)\end{array}$ \\
\hline
\end{tabular}

${ }^{\star} \mathrm{TK}=$ total kill, $\mathrm{T}=$ only $10 \mathrm{cfu} / \mathrm{ml}$ remaining, $\mathrm{LT}=<10 \mathrm{cfu} / \mathrm{ml}, \mathrm{TK}, \mathrm{L}=$ total kill or $<10 \mathrm{cfu} / \mathrm{ml}$. $\mathrm{n}=$ number of lenses used in each group, $\mathrm{N}=$ number of test runs.

HWI $=$ high water content ionic lenses.

$\mathrm{LWN}=$ low water content non-ionic.

Table 2 The use of multipurpose solutions with the device

\begin{tabular}{|c|c|c|c|c|}
\hline \multirow[b]{2}{*}{ Testing procedure } & \multicolumn{4}{|c|}{ Test organisms, solutions, and log reductions after testing (cfu/ml) } \\
\hline & Lens type & $\begin{array}{l}S \text { aureus } \\
\text { SOLOCare } 1^{*}\end{array}$ & $\begin{array}{l}P \text { aeruginosa } \\
\text { Complete } 2^{\star}\end{array}$ & $\begin{array}{l}S \text { marcescens } \\
\text { SOLOCare } 3^{*}\end{array}$ \\
\hline Test & $\begin{array}{l}\text { HWI } \\
(\mathrm{n}=4)\end{array}$ & $\begin{array}{l}3.0 \\
(\mathrm{SD}=0.17) \\
(\mathrm{N}=4)\end{array}$ & $\begin{array}{l}6.0(\mathrm{LT}) \\
(\mathrm{SD}=0) \\
(\mathrm{N}=4)\end{array}$ & $\begin{array}{l}7.0(\mathrm{TK}) \\
(\mathrm{SD}=0) \\
(\mathrm{N}=3)\end{array}$ \\
\hline Control & $\begin{array}{l}\text { HWI } \\
(\mathrm{n}=4)\end{array}$ & $\begin{array}{l}1.0 \\
(\mathrm{~N}=4)\end{array}$ & $\begin{array}{l}2.0 \\
(\mathrm{~N}=4)\end{array}$ & $\begin{array}{l}1.0 \\
(\mathrm{~N}=3)\end{array}$ \\
\hline Test & $\begin{array}{l}\mathrm{LWN} \\
(\mathrm{n}=4)\end{array}$ & $\begin{array}{l}(\mathrm{SD}=0.44) \\
(\mathrm{N}=4)\end{array}$ & $\begin{array}{l}6.0 \\
(\mathrm{SD}=0) \\
(\mathrm{N}=4)\end{array}$ & $\begin{array}{l}7.0(\mathrm{TK}) \\
(\mathrm{SD}=0) \\
(\mathrm{N}=3)\end{array}$ \\
\hline Control & $\begin{array}{l}\mathrm{LWN} \\
(\mathrm{n}=4)\end{array}$ & $\begin{array}{l}2.0 \\
(\mathrm{~N}=4)\end{array}$ & $\begin{array}{l}2.0 \\
(\mathrm{~N}=4)\end{array}$ & $\begin{array}{l}1.0 \\
(\mathrm{~N}=3)\end{array}$ \\
\hline
\end{tabular}

${ }^{\star}$ Results after 1,2, and 3 minutes with SOLOCare and Complete.

$\mathrm{TK}=$ total kill, $\mathrm{T}=$ only $10 \mathrm{cfu} / \mathrm{ml}$ remaining, $\mathrm{LT}=<10 \mathrm{cfu} / \mathrm{ml}$.

$\mathrm{n}=$ number of lenses used in each group, $\mathrm{N}=$ number of test runs.

HWI $=$ high water content ionic lenses.

LWN = low water content non-ionic.

micro-organisms recovered. The results accumulated from consecutive recoveries can then be evaluated. Test and control procedures were performed using normal saline.

\section{Results}

Six out of 10 tests resulted in either complete removal of challenge organisms from lenses, or reductions to $10 \mathrm{cfu} / \mathrm{ml}$ or $<10 \mathrm{cfu} / \mathrm{ml}$. Control lenses averaged only a $2.3-2.5 \mathrm{log}$ reduction of test organisms (Table 1).

EVALUATION WITH CONTACT LENS SOLUTIONS The device was tested as described for saline, but substituting multipurpose solutions for saline. The treatments were performed in various cleaning cycles as illustrated in Table 2 .

The results summarised in Table 2 show that a 1 minute cleaning cycle using SOLOCare (Ciba Vision) achieved a 3-4 log reduction of $S$ aureus from the lenses. The 2 minute cleaning cycle using Complete (Allergan) showed a $6 \log$ reduction of $P$ aeruginosa from lenses, and the 3 minute cleaning cycle using SOLOCare resulted in eradication of $S$ marcescens.

EVALUATION WITH LENS CARE SOLUTIONS ON LABORATORY BIOFILMS

An experimental procedure developed at Moorfields Eye Hospital was used to produce simulated biofilms. The device was tested as described for saline but substituting 10:10 hydrogen peroxide (Ciba Vision) or Optifree (Alcon) for saline. The treatments were performed in two cleaning cycles and the results were as follows.

The device when used with Miraflow and 10:10 solution eradicated bacterial biofilm on the lenses. After 2 minutes of cleaning there was no recovery of the test organism. The device when used with Opticlean and Optifree showed a $>10 \log$ reduction of planktonic challenge organisms.

\section{Discussion}

This lens cleaning device when used with normal saline alone met the criteria given in the International Standards Organisation's directive ISO/CD14729.3, which gives performance tests using bacteria and fungi. Previous studies have shown that physical rubbing of a lens with cleaning solutions can reduce micro-organisms by $10^{2}-10^{3} \mathrm{cfu} / \mathrm{ml}$ or more. ${ }^{411}$ However, reports show that $32 \%$ of users do not clean their lenses at all after each use. ${ }^{12}$ The hands of a lens wearer may transfer contamination to a contact lens during cleaning and/or general lens manipulation. ${ }^{13}$ The new cleaning device minimises the use of the hands in lens maintenance while increasing cleaning efficacy. It is safe to use with soft, PMMA, and gas permeable contact lenses and does not change their surface properties.

Studies of Acanthamoeba keratitis report that contamination of a contact lens case with bacteria can support amoebae and enable them to feed. ${ }^{14}$ The cleaning device not only cleans lenses but also cleans its own storage case simultaneously, thus reducing the chance of lens case contamination.

Preliminary tests using a hydrogen peroxide care product surpassed the criteria given in ISO/CD14729.3 and showed a >10 log reduction of the challenge organisms. Incubating the lenses for 72 hours after cleaning showed minimal growth $(100 \mathrm{ml}$ with Pseudomonas aeruginosa), but no colony forming units could be detected. Similar results were achieved when using Optifree and SOLOCare for 2-3 minutes.

This device should help to significantly reduce contact lens wear complications that are associated with inadequate contact lens care procedures or contaminated contact lens cases.

The authors thank John K G Dart, Michael Port, and David Shannon for their assistance in the preparation of the manuscript.

The authors also thank Shannon \& Carton and Dolland \& Aitchison for the supply of contact lenses.

C P Ifejika has an interest in the company LensCare Ltd.

1 Caberera HV, Rodriguez JB. Ocular bacterial flora in contact lens wearers. Int Contact Lens Clin 1996;23:149-51. 2 Dart JKG. Disease and risks associated with contact lenses. Br F Ophthalmol 1993;77:49-53.

3 Kanpolat A, Kalayci D, Arman D, et al. Contamination in contact lens care systems. CLAO f 1992;18:105-7.

4 Houlsby RD, Ghajar M, Chavez G. Microbiological evaluation of soft contact lens disinfecting solutions. 7 Am Optom Assoc 1984;55:205-11.

5 Sousa LB, Mannis MJ, Schwab IR, et al. The use of synthetic cecropin $\left(\mathrm{D}_{5} \mathrm{C}\right)$ in disinfecting solutions. $C L A O \mathcal{F}$ 1996;22:115-17.

6 Rosenthal RA, Stein JM, McNally CL, et al. A comparative study of the microbiologic effectiveness of chemical disinfectants and peroxide-neutraliser systems. CLAO $\mathcal{f}$ 1995;21:99-109. 
7 Borlace LM, Rogers J, Dart JKG. Culture, vital staining and microscopy of contact lens case biofilms. Article presented at the ARVO conference general meeting, 1997.

8 Wilson LA, Sawant AD, Simmons RB, et al. Microbial contamination of contact lens storage cases and solutions. $A m$ F Ophthalmol 1990;110:193-8.

9 Matthews TD, Frazer DG, Minassian DC, et al. Risks of keratitis and patterns of use with disposable contact lenses. Arch Ophthalmol 1992;110:1559-62.

10 Hay J, Seal DV, Connor R, et al. Disinfection and sonification: Effect on association of Acanthamoeba cysts with an ionic, high-water content hydrogel contact lens. $\mathcal{F}$ Br Contact Lens Assoc 1995; 18:5-7.
11 Efron N, Lowe R, Vallas V, et al. Clinical efficacy of standing wave and ultrasound for cleaning and disinfecting contact lenses. Int Contact Lens Clin 1991;18:24-9.

12 Key JE, Monnat K. Comparative disinfectant efficacy of two disinfecting solutions against Pseudomonas aeruginosa. CLAO 7 1996;22:118-21.

13 Holden BA, Hood DL, Grant T, et al. Gram negative bacteria can induce contact lens related acute red eye (CLARE) responses. CLAO f 1996;22:47-51.

14 Gray TB, Cursons TM, Sherwan JF, et al. Acanthamoeba, bacterial, and fungal contamination of contact lens storage cases. Br F Ophthalmol 1995;79:601-5. 